\title{
DIRECT DETECTION OF MYCOBACTERIUM TUBERCULOSIS AND MYCOBACTERIUM BOVIS IN CATTLE RAW MILK BY USING SPECIES -SPECIFIC PCR TECHNIQUE
}

\author{
R.A. Al-SANJARY; O.H. SHEET and Dh.M.T. JWHER \\ Department of Veterinary Public Health, Collage of Veterinary Medicine, University of Mosul, Mosul-Iraq
}

\section{ABSTRACT}

Received at: 18/10/2012

Accepted: 26/12/2012
Fifty samples of raw cow milk were collected from clinically infected animals from different regions of Mosul city-Iraq, during the period between July to November, 2011 for direct detection of Mycobacterium tuberculosis and Mycobacterium bovis in the milk by using species-specific PCR technique. The Sacace MTB complex kit was used for DNA extraction and amplification from these samples. The Results showed that only four samples from fifty samples of suspected infected milk cow's were positive at ratio $(8 \%)$. These results ensured the occurrence of M. tuberculosis and M. bovis in the milk transmitted from animals to human and vice versa which may cause human tuberculosis, the study enhanced the significance of bacterial presence in raw milk and cause the infection to the consumer by drinking the contaminated or unpasteurized milk.

Key words: Cow milk, M. tuberculosis and M. bovis, PCR technique.

\section{INTRODUCTION}

Mycobacterium tuberculosis complex (MTC) are main causative agents of tuberculosis in many types of animals, birds and human. They are comprised of several types of species such as Mycobacterium tuberculosis causing human tuberculosis which is considered as one of the most important zoonotic disease and distributed throughout the world. and it is one member of Mycobacterium tuberculosis complex (Cole et al., 1998; Alexander et al., 2010). Bovine tuberculosis is also an important zoonotic disease which is caused by Mycobacterium bovis. The main reservoir of $M$. bovis infections is the infected cattle which served as the source of infection for human (Grange et al., 1996). Bovine tuberculosis is easily transmitted from cattle to other and from cattle to human (Cousins and dawson et al., 1999). Man usually get infection through contacts with the infected animals or by taking their contaminated raw milk and other milk products with the M. bovis bacteria (Ayele et al., 2004; Collins and Grange et al., 2003).

The human tuberculosis remains a major public health problem in the world, the rate of third and there are about 3 million human death annually (Cornejo et al., 1998). The Nigerian human population carries the largest tuberculosis in Africa and it is of the fourth largest in the world which is estimated 390,000 human infections and 107,000 death per year (WHO, 1994). In 2004, the report of WHO showed that the mortality and morbidity statistics were 14.6 million chronic active cases, 8.9 million new cases and 1.6 million death. Most infection cases occur in developing countries and the rate of infections increased were about $1 \%$ annually (WHO, 2006).

The disease in cattle is distributed in all the worldwide, there is no information about geographical boundaries of the disease. The clinical signs usually appear after one month of ingestion or inhalation of the bacilli and the disease appear when animals are exposed to stress or they appear in the old age. On the other hand, some cases of the infections can remain dormant for several years (Cousins, 2001).

The isolation of bacteria is highly specific but has poor sensitivity and it takes much time and intensive labor. Isolation of $M$. bovis via traditional culture methods may require 4-8 weeks (Sommers and Wood, 1985). There are several modern identification methods using DNA amplification techniques which have been developed for diagnosis of Mycobacterium tuberculosis complex (Smith et al., 2006). Nucleic acid based on amplification techniques of which the Polymerase Chain Reaction has been so far the most extensively employed, offer several advantages over the classical microbiological methods such as shorter time of analysis, low detection limits, specificity and high sensitivity, thus PCR could be used as a screening technique (when performed at the herd level) or as a diagnostic technique (Kolk et al., 1992; Vitale, 1998 and WHO, 2009).

Identification of the etiological agent belonging to MTC is important for determining the origin and reservoirs of infection and also for implementation of appropriate public health measures. The aim of this 
study is to identify the incidence rate of Mycobacterium tuberculosis and mycobacterium bovis in raw milk of cattle in Nineveh governorate by using direct species-specific PCR technique which is considered a rapid method to detect the disease compared with the traditional method.

\section{MATERIALS and METHOD}

Fifty samples of raw cow's milk were collected from different regions of cattle farms in Mosul city during the period of July, to November, 2011, $10 \mathrm{ml}$ of milk was collected in the sterile test tube and transport to the research lab of department of veterinary public health in the college of veterinary medicine, and stored in deep freeze at $\left(-20 \mathrm{C}^{\circ}\right)$ until used for DNA extraction process. For preparation the samples before extraction of DNA, $10 \mathrm{ml}$ of milk sample is centrifuged at $3000 \mathrm{~g} / \mathrm{min}$ for $10-15 \mathrm{~min}$. The supernatant was discard. If the pellet is not visible, add $10 \mathrm{ml}$ of distilled water and repeat centrifugation and discard the supernatant. Resuspend the pellet in $100 \mu \mathrm{l}$ of saline solution.

\section{DNA extraction}

Mycobacterium tuberculosis and bovis DNA was extracted using commercial DNA extraction kit (Sacace Biotechnology Srl, Italy). According to manufacture instructions prepare required quantity of $1.5 \mathrm{ml}$ polypropylene tubes including one tube for Negative Control of Extraction. Add to each tube 10 $\mu \mathrm{l}$ of Internal Control and $300 \mu \mathrm{l}$ of Lysis Solution. Add $100 \mu \mathrm{l}$ of samples to the appropriate tube. Vortex the tubes and incubate for $5 \mathrm{~min}$ at $65^{\circ} \mathrm{C}$. centrifuge all tubes for $30 \mathrm{sec}$ at $8000 \mathrm{~g}$ and using a micropipette with a plugged aerosol barrier tip, carefully remove and discard supernatant from each tube without disturbing the pellet. Add $300 \mu$ of washing Solution 1 to each tube. Vortex vigorously and centrifuge for $30 \mathrm{sec}$ at $8000 \mathrm{~g}$. Remove and discard supernatant from each tube. Add $500 \mu \mathrm{l}$ of washing solution 2 to each tube. Vortex vigorously and centrifuge for 30 $\mathrm{sec}$ at $8000 \mathrm{~g}$. Remove and discard supernatant from each tube. Resuspend the pellet in $50 \mu$ of DNAeluent. Incubate for $5 \mathrm{~min}$ at $65^{\circ} \mathrm{C}$ and vortex periodically. Centrifuge the tubes for $1 \mathrm{~min}$ at maximum speed (12000-16000 g). The supernatant contains DNA ready for amplification. If amplification is not performed the same day of extraction, stored at frozen at $20^{\circ}$.

\section{Amplification}

Prepare required quantity of tubes PCR-mix-1. Pipette $10 \mu \mathrm{L}$ of PCR-mix-2 into each PCR-mix-1 tube. Add to appropriate tube $10 \mu \mathrm{L}$ of DNA sample obtained after sample preparation. Add $10 \mu \mathrm{L}$ of DNA-buffer to the tube for negative control of amplification. Add $10 \mu \mathrm{L}$ of positive control (dilute 1:10 with DNA buffer) to the tube for positive control of amplification. Close PCR-mix-1 tubes and transfer them into the thermalcycler only when temperature reaches $105{ }^{\circ} \mathrm{C}$ and start the following program, one cycle at $95^{\circ} \mathrm{C}$ for $5 \mathrm{~min}, 32$ cycle ( step 1: $95^{\circ} \mathrm{C}$ for $30 \mathrm{~s}$, step $2: 70{ }^{\circ} \mathrm{C}$ for $30 \mathrm{~s}$, step $3: 72^{\circ} \mathrm{C}$ for $1 \mathrm{~min}$ ), finally one cycle at $72{ }^{\circ} \mathrm{C}$ for $7 \mathrm{~min}$, according to the Sacace MTB complex kit. Analysis of results is based on the presence or absence of specific bands of amplified DNA in agarose gel $(2 \%)$ staining by ethidum bromide. The length of specific amplified DNA fragments is $390 \mathrm{bp}$ for Mycobacterium tuberculosis \& bovis which visualized by using UV transilluminator and digital camera.

\section{RESULTS and DISCUSSION}

Milk and its products are regarded as the main source of nutrition to human being, on the other hand, they are considered as a good medium for many types of pathogenic bacteria and transmit the disease from animals to human through consumption the contaminated or unpasteurized milk (Sweeney et al., 1992).

The result showed that only four samples from fifty milk samples collected from clinically infected cattle were positive and the incidence rate was $8 \%$. Polymerase chain reaction (PCR) is considered as one of the most important modern technique in the world for being rapid, sensitive, and the practical technique which based on the amplification of highly specific DNA sequences present in the agent of interest in different samples by giving amplified bands weighted $390 \mathrm{bp}$ when electrophoresed on $2 \%$ agarose gel staining with ethidium bromide (Tiwari et al., 2007), showed in figure (1).

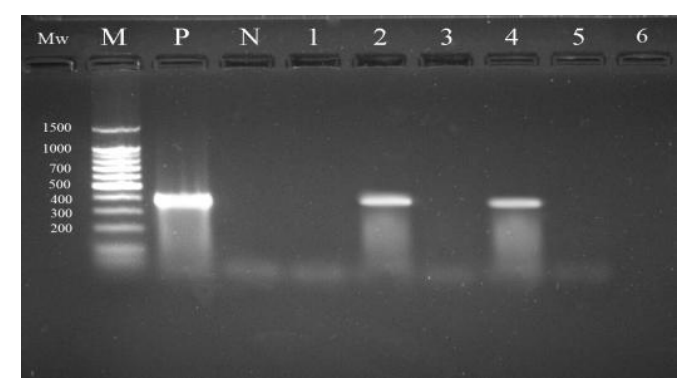

Figure (1): PCR amplification results of $M$. tuberculosis and bovis appeared at 390 bp. M : DNA Ladder, $\mathrm{P}$ : positive control, $\mathrm{N}$ : negative control, 2 and 4 amplified fragments for Mycobacterium spp. were separated by electrophoresis on a $2 \%$ agarose gel stained with ethidium bromide, $1,3,5$ and 6 negative for Mycobacterium spp.

The incidence rate obtained from this study is similar to the previous study (Sulieman et al., 2008) which showed the rate of infection is $(8.64 \%)$, while the rate of incidence of our study is less than the previous study (Ameni et al., 2007; Naima et al., 2008; Al-Saquar et al., 2009 and Gobena, 2010) which are recorded $(46.8 \%),(29 \%),(10.2 \%)$ and $(53.6 \%)$ 
respectively, the high incidence rate of the previous studies is attributed to the collection of the samples from infected cattle herds, and also from the developing countries, they do not have any effective programs to prevent the occurrence of the disease in the cattle herd (Cassidy, 2006), while the rate of infection of our study is high from (Ofukwu et al., 2008) which recorded $(1.4 \%)$ this is attributed to use the conventional method to detect the Mycobacterium tuberculosis complex that it is commonly used in the developing countries to identify the infected animals (Gilbert et al., 2005).

The type of the method used to detect mycobacterium tuberculosis complex plays a major role in detection of the disease between the cattle herd. In developing countries that use the conventional method to detection instead of tuberculin skin test and selective culture media. Mycobacteria grow slowly and the growth of these bacteria appeared after several weeks and the result was confirmed by biochemical test to detect the mycobacterium (Palmer and Waters, 2006). Therefore, we must use rapid and sensitive method to reach accurate diagnosis because administration of the antibiotic without taking any recommendation from veterinarians is very dangerous and it may cause an increase in the resistance of mycobacterium tuberculosis complex to antibiotic by sequential acquisition of chromosomal mutation (Sebastien et al., 2006).

Although the cattle included in the studied areas are not reared intensively, but the source of infection is expected due to lack of control and eradicate programs of the disease in Iraq as well as mismanagement, lack of veterinary care, lack of biosecurity program and malnutrition, where cattle leave for long period outside the barns with bad rations, pushing the cattle grazing in waste contaminated areas and as well as connection with other domestic and wild animals, all of these factors may lead to increased exposure to the disease (Al-Saqur, 2009).

\section{Acknowledgment}

Authors wish to thank the college of veterinary medicine, University of Mosul for supporting and providing facilities to complete the research.

\section{REFERENCE}

Alexander, K.A.; Laver, P.N. and Michel, A.L. (2010): Novel Mycobacterium tuberculosis complex pathogen, Mycobacterium mungi. Emerging infectious diseases. 16: 1296-1299.

Al-Saquar, I.M.; Al-Thwani, A.N. and Al-Attar, I.M. (2009): Detection of Mycobacteria spp in cows milk using conventional methods and PCR. Iraqi J. Vet. Med. 23: 259-262.
Al-Saqur, IM.; Al-Thwani, A.N. and Al-Attar, I.M. (2009): Detection of Mycobacteria spp. in cows milk using conventional methods. and PCR, Iraqi Journal of Veterinary Sciences. 23: 259-262.

Ameni, G.; Sofa, A.; Engers, H.; Young, D.; Gordon, S.; Harwinton, $G$. and Vordermeier, $M$. (2007): High prevalence and increased sensitivity of pathology of bovine tuberculosis in Holsteins compared with Zebu breed under field cattle husbandry in central Ethiopia. Clin. Vaccine Immunol. 14: 1356-1361.

Ayele, W.Y.; Ncill, S.D.; Zinsstag, J.; Weiss, M.G. and Pavlik, I. (2004): Bovine tuberculosis: an old disease nut a new threat to Africa. The International $\mathrm{J}$. of tuberculosis and lung disease. 8: 924-937.

Cassidy, I.P. (2006): The pathogenesis and pathology of bovine tuberculosis with insights from studies of tuberculosis in humans and laboratory animal modals. Vet. Microbiol. 112: 151-161.

Cole, S.T.; Brosch, R.; Parkhill, J.; Garnier, T.; Churcher, C.; Harris, D.; Gorden, S.V.; Eiglmeier, K.; Gas, S. and Barr, C.E. (1998): Deciphering the biology of mycobacterium tuberculosis from the complete genome sequence. Nature. 393: 537-544.

Collins, C.H. and Grange, J.M. (2003): Mycobacteria in: Caballero B, Trugo L, Finglas $\mathrm{P}$ (eds) Encyclopedia of food sciences and nutrition. Elsevier, Amsterdam, Netherlands. 4067-4072.

Cornejo, B.J.; Sahagun-Ruis, A.; Suarez gumes, F.; Thornton, C.G.; Ficht, T.A. and Adams, L.G. (1998): Comparison of 18carboxyropylbetaine and glass bead DNA extraction methods for detection of mycobacterium bovine in bovine milk samples and analysis of samples by PCR. Appl. Environ. Microbiol. 64: 3099-3101.

Cousins, D.V. (2001): Mycobacterium bovis infection and control in domestic livestock. Rev. Sci. Tech. 20: 71-85.

Cousins, D.V. and Dawson, D.J. (1999): Tuberculosis due to mycobacterium bovis in the Australian population :cases recorded during 1970-1994. International Journal of tuberculosis and lung disease. 8: 715-721.

Gilbert, M.; Mitchell, A.; Bourn, D.J.R.; CliftonHadley Wint, W. (2005): Cattle movement and bovine tuberculosis in great Britain. Nature. 435: 491-496.

Gobena, A. (2010): Conventional and molecular epidemiology of bovine tuberculosis in dairy farms in Addis Ababa city, the capital of Ethiopia. Inter. J. Appl. Res. Vet. Med. 8, 2: 143-151.

Grange, J.M.; Malcolm, D.; Isabel, N. and de Kantor (1996): Guidelines for speciation within the mycobacterium tuberculosis complex. Second 
edition (PDF). World Health Organization. Retrieved on 2007.

Kolk, A.H.J.; Schuitema, A.R.J. and Kuijper, S. (1992): Detection of Mycobacterium tuberculosis in clinical samples by using polymerase chain reaction and a nonradioactive detection system. J. Clin. Microbiol., 30: 2567-2575.

Naima, M.; Zafar, I.C.; Nasir, M. and Shakoori, A.R. (2008): Readability of OCR for detection of bovine tuberculosis in Pakistan. Pakistan J. Zool. 40, 5: 347-351.

Ofukwu, R.A.; Oboegbulem, S.I. and Akwuobu, C.A. (2008): Zoontic Mycobacterium species in fresh cow milk and skimmed, unpasteurized market milk (nonn) in Makurdi, Nigeria: implications for public health. J. of animal and plant sciences. 1, 1: 21-25.

Palmer, M.V. and Waters, W.R. (2006): Advances in bovine tuberculosis diagnosis and pathogenesis: what policy markers need to know. Vet. Microbiol., 112: 181-190.

Sebastien, G.; Clara, D.L.; Peter, M.S.; Tran, V.; Gary, K.S. and Brendam, J.M. (2006): The competitive cost of antibiotic resistance in mycobacterium tuberculosis. Science. 312: 1944-1946.

Smith, N.H.; Gordon, S.V.; de la Rua-Domenech, R.; Clifton-Hadley, R.S. and Hewinson, R.G. (2006): Bottlenecks and broomsticks: the molecular evolution of Mycobacterium bovis. Nat. Rev. Microbiol. 4: 670-681.

Sommers, H.M. and Wood, R. (1985): Mycobacterium. In: Manual of clinical microbiology, pp. 216-248. ASM Press, Washington, DC.

Sulieman, M.S.; Hamid, M.E. and Purandas, M. (2008): Bovine tuberculosis in dairy animals at Lahore, threat to the public health 2002. (Cited by: Naima M, Zafar IC, Nasir M, Shakoori AR. Readability of PCR for detection of bovine tuberculosis in Pakistan. Pakistan J. Zool. 40, 5: 347-351.

Sweeney, R.W.; Whitlock, R.H. and Rosenberger, A.E. (1992): Mycobacterium tuberculosis cultured from milk, lymph node of infected caw .J clinical Microbial. 30: 166-171.

Tiwari, R.P.; Hattikudur, N.S.; Bharmal, R.N.; Kartikeyans, S.; Deshmukh, N.M. and Bisen, P.S. (2007): Modern approaches to a rapid diagnosis of tuberculosis: promises and challenges a head. Tuberculosis. 87: 193-201.

Vitale, F.; Capra, G. and Maxia, L. (1998): Detection of Mycobacterium tuberculosis complex in cattle by PCR using milk, lymph node aspirates, and nasal swabs. J. Clin. Microbiol. 36: 1050-1055.

WHO (World Health Organization). (1994): Zoontic tuberculosis (mycobacterium bovis). Memoranda from WHO/FAO meeting. Bulletin of the WHO. 72, 6: 851-857.

WHO (World Health Organization). (2009): Epidemiology. WHO report 2009 Global tuberculosis control. 6-33.

WHO (World Health Organization). (2006): Tuberculosis fact sheet $\mathrm{N}^{\circ} 104-$ Global and regional incidence.

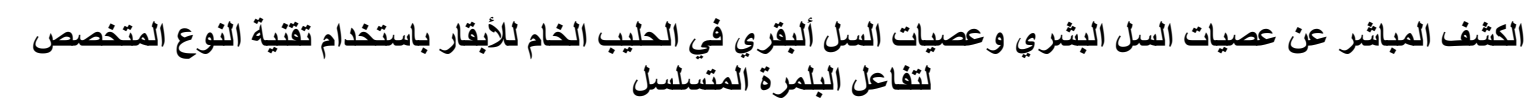

رعد عبل الغتسي السنجري ، عدر هاثم شبيث ، ضياء محد طاهر جوهر

جمعت (50) عينة حليب خام من أبقار مصابة سريريا من حقول الأبقار في مناطق مختلفة من مدينة الموصلـ العراق، للفترة مابين شهر تموز إلى إنى

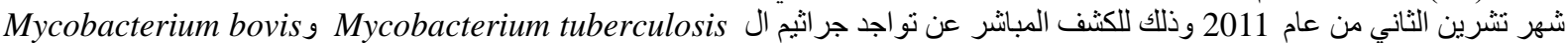

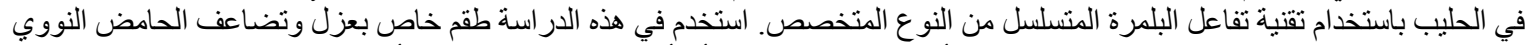

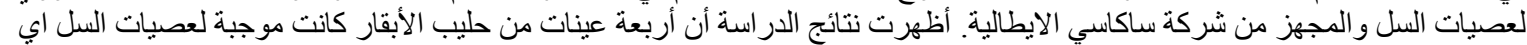

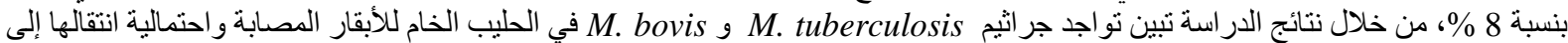

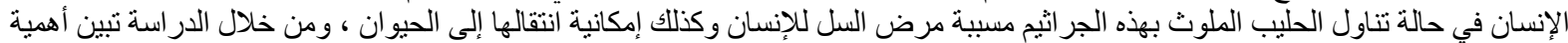

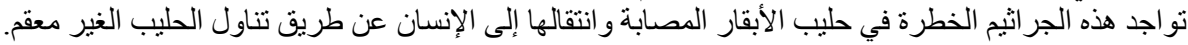

